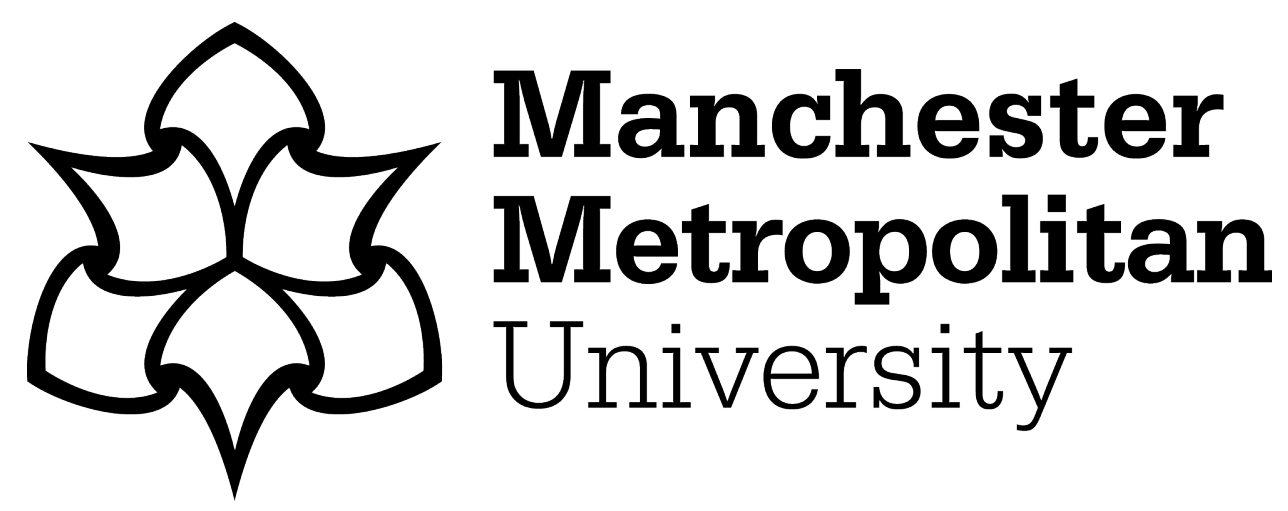

Carter, Matthew ORCID logoORCID: https://orcid.org/0000-0003-2536-775X (2020) The Perpetuation of Myth: Ideology in Bone Tomahawk. Zeitschrift für Anglistik und Amerikanistik: a quarterly of language, literature and culture, 68 (1). ISSN 0044-2305

Downloaded from: https://e-space.mmu.ac.uk/624303/

Version: Accepted Version

Publisher: Walter de Gruyter

DOI: https://doi.org/10.1515/zaa-2020-0004

Please cite the published version 


\title{
The Perpetuation of Myth: Ideology in Bone Tomahawk
}

\begin{abstract}
The contemporary Western Bone Tomahawk is in the tradition of the settlerversus-Indian stories from the genre's 'classical' period. Its story is informed by one of white America's oldest and most paranoiac of racist-psychosexual myths: the captivity narrative. This article reads Bone Tomahawk's figuration of the racial anxieties that inhere within nineteenth-century settler-colonial culture in the context of post-9/11 America. It also considers that the film's imbrication of Horror film conventions into its essential Western framework amplifies its allegorical representation of contemporary America's cultural and political-ideological mindset. As well, the use of Horror conventions amplifies the racial anxieties generated by its use of a mythic binary construct of an adversarial relation of whites to 'Indians.' To a lesser extent, the article suggests that the film also embodies certain uncontained ideological contradictions that, though undeveloped, could be said to contest its ideological coherence.
\end{abstract}

\section{Introduction}

Independently produced for $\$ 1.8$ million and shot over twenty-one days, Bone Tomahawk (2015), the debut feature of writer-director S. Craig Zahler, is a contemporary Western set in the traditional confines of Hollywood's frontier. The story centers on injured cowpoke Arthur O'Dwyer (Patrick Wilson) and his desperate attempt to rescue his kidnapped wife, Samantha (Lili Simmons), from the clutches of a mysterious warrior tribe.

\footnotetext{
* Corresponding author: Dr. Matthew Carter, Department of English, Manchester Metropolitan University, All Saints, Manchester, M15 6BH, UK, e-mail: m.carter@mmu.ac.uk
} 
Setting this nightmare scenario in chain are two outlaws, Buddy (Sid Haig) and Purvis (David Arquette), who happen across a macabre burial mound in the desert. Buddy is soon killed by a shadowy assailant and Purvis flees. Seeking refuge in the frontier settlement of Bright Hope, he is immediately eyed with suspicion by Sheriff Franklin Hunt (Kurt Russell), who shoots him in the leg and throws him in jail. Local nurse Samantha is summoned to tend to the wound. Leaving her in the care of his deputy, Nick (Evan Jonigkeit), Hunt retires for the evening. But Purvis has unwittingly led those who killed Buddy back to Bright Hope and later that night unearthly howling is heard around town. Next morning, Hunt is alerted to the discovery of the mutilated corpse of Buford (Jeremy Tardy), a black stablehand, and of the jailhouse being empty. A discarded arrow suggests that 'Indians' murdered Buford and likely abducted Samantha, Nick, and Purvis. Hunt informs Arthur, who is convalescing at home with a broken leg, and the two determine to get Samantha back. Accompanying them will be Hunt's comical 'back-up deputy,' Chicory (Richard Jenkins), and self-professed 'Indian killer,' John Brooder (Matthew Fox). At The Learned Goat Saloon, the town's resident 'expert,' a Native American known as 'the Professor' (Zahn McClarnon), informs Hunt that the culprits are not his "kind," that is, not "Indians," but rather insidious cannibal "troglodytes" that live beyond the pale of civilization in the "Valley of the Starving Men." Disregarding the Professor's warning that they face certain death, the four men set off on horseback to recover the captives.

For a Western produced in the second decade of the twenty-first century to use such a racially problematic premise as 'Indian abduction' in so unregenerate a fashion certainly raises some uncomfortable questions about what the film might mean as a Western in the contemporary context. This is especially so considering the extent to which Bone Tomahawk pronounces its traditional characteristics. A few scenes of graphic violence notwithstanding, the film's overall narrative schema - visual style, pacing, character-types, geo-historical 
setting, dialogue, humor - is largely tonally contiguous with the 'settler-versus-Indian' stories of the genre's 'classical' period. At the risk of courting paradigmatic reduction, this plot-type generally depicts Native Americans as 'savages' threatening white protagonists and settler communities. Projecting savagery outwards onto the Indian served to motivate white America's fear of its foundational 'Other' and formed part of the broader cultural history of a society eager to disavow its dark colonialist legacy. The act of disavowal helped to reimagine white America's violent history of expansion and settlement as a heroic 'myth of origins' that served to disguise (or at least justify) the fate of the land's original inhabitants. It fed into the very frontier mythos upon which such settler communities were originally founded, and from which they drew their sense of historical legitimacy.

In its portrayal of members of a settler community under threat from an implacable indigenous enemy, Bone Tomahawk forces consideration of its ideological functionality as a Western within this very context. This requires us to engage with, and offer explication of, the genre's own problematic legacy of implicit and often explicit racism toward Native Americans vis-à-vis its long-running association with this mythic version of history. Broadly speaking, discussion of Bone Tomahawk's figuration of the racial anxieties that inhere within America's settler-colonial culture can be framed within "the Western's mythical polarity between savage Indians and civilizing pioneers" (Cawelti 1999, 105). At the same time, we should not discount the extent to which any text is the product of the times in which it was written. Zahler wrote his script for Bone Tomahawk in the 2010s - the period of the post-9/11 War on Terror. Thus we may interpret the ambience of the film as a reflection of the fears and anxieties generated by this era. I also suggest we read the film, not only in this context as a Western, but also in the context of the Horror film. Evidently, Bone Tomahawk imbricates Horror conventions into its essential Western framework. For the purposes of this article, I propose two interrelated points of interest: first, that this amplifies the film's allegorical 
representation of America's cultural and political-ideological mindset post-9/11; second, that it amplifies the racial anxieties generated by its use, as a Western, of the frontier myth's binary construction of an adversarial relation of whites to Indians.

This is not to suggest that Bone Tomahawk be wholly reducible to a reflection of a dominant ideology contemporaneous to the period of its production. Nor that it function unambiguously as a vehicle for the promulgation of the Western myth. At its core, Zahler's film does represent a reactionary political ideology, but at the same time Westerns are rarely ideologically monolithic. To varying degrees, they represent texts in tension, highlighting the ideological contradictions contained within the dominant ideological positions they assume. As Susan Kollin argues, "even classic Westerns contain moments of resistance and selfreflection, carrying with them their own critique." The converse is also true, as "revisionist" Westerns "preserve moments of desire, moments of connection and identification with elements of the classic Western" (Kollin 2001, 560). Analyzing recent cycles of the genre, Andrew Patrick Nelson marks "the degree to which the contemporary Western evidences a tension, or negotiation, between a revisionist impulse inherited from the 1960s and 1970s and broader classical conventions that continue to shape the genre" (Nelson 2013, xviii). Finally, hybridity also has an "impact on the ideological landscape of the Western," which Emma Hamilton and Alistair Rolls discuss in terms of a "collision [of] various genre elements," and of the resulting "tension that comes from this collision under the banner of the Western" (Hamilton 2018, 19).

If Bone Tomahawk amplifies its dominant ideological position in the manner that I propose, it follows that this would also amplify the inherent contradictions that this ideology seeks to contain, and would simultaneously uncontain them. This is to say the film is characterized by the possibility of 'reading against the grain.' But before analyzing Bone Tomahawk directly, it is important to create a context in which to consider the role of 
racialization and the representation of Native Americans in the Western and to set these stereotypes in their relation to frontier mythology.

\section{Native Americans, Frontier Mythology, and the Western}

As one of the foundational ideological constructs of the myth, the struggle between civilization and savagery served to reduce historical complexities of settler-indigene conflict to a binarism of good-versus-evil. It fed public desire for a heroic interpretation of its own past and underscored the values that were at stake in the establishment of the nation as a whole. At the heart of the myth lay the notion of the bringing of civilization (conceived as white) to areas that were, paradoxically, both 'empty wilderness' and inhabited by 'inferior races.' This process of mythopoesis is, of course, an essential part of the process whereby any dominant ideology is legitimized. Here, the purpose was to naturalize the racialist discourses of American exceptionalism and Manifest Destiny. Under the politico-religious auspices of which, the cultural and material extirpation of the Native American was justified in the name of the 'domestication of the wilderness' and 'nation-building.'

Richard Slotkin details how this violent "myth-historiography" sought to "advance the fortunes of White colonists" through the powerful symbol of "savage war" (Slotkin 1992, 11). Utilizing an ideological conceit that typically "blame[d] Native Americans as instigators of a war of extermination," savage war made conflict between settler and native "ineluctable," and justified the settlers' annihilatory "response" to the asserted "bloodthirsty propensity of the natives" (Slotkin 1992, 12). This scapegoating of the Indian is best "understood as an act of psychological projection [...] for the morally troubling side of American expansion," with the myth of savage war functioning as "a basic ideological convention of a culture that was itself increasingly devoted to the extermination or expropriation of the Indians" (Slotkin 1992, 13). One of the most potent themes through 
which savage war was expressed was the 'captivity narrative.' Tales of the abduction of white settlers, especially of white women settlers, have featured in American literary output from the time of the first arrival of Europeans and constitute one of white America's oldest, most paranoiac of racist-psychosexual discourses. "Her captivity," observes Slotkin, "is a figurative descent into Hell," her rescue by "the American hero-as-Indian-fighter" and his revenge against the perpetrators fully-justified and culturally-coded as a "triumph of civilization over savagery" (Slotkin 1992, 14-15).

In the "modern" era, these fundamental tenets of the myth were developed in the Western, which, according to Richard Maltby, asserted "the right to rewrite history in the name of free mythopoeia" (Maltby 1996, 36). Scapegoating Native Americans ensured that "there are no 'real' Indians" in the genre, merely imposed stereotypes "derived from the earlier traditions of the dime novel, the historical romance, and the captivity narrative" (Maltby 1996, 35). Reduced, as Douglas Pye has it, to "terms in the generic equation" (Pye 1996, 234), the Native American held a symbolic function, a mirror or foil for the values represented by hegemonic patriarchal white settler-colonial society. Even when films did deal specifically with Native American representation, they frequently approached their presence as stand-ins for a variety of other groups instead of viewing them as representatives of their own culture. Thus conceived Indians constitute either mythic representations of Otherness that the dominant race both need and fear, or else mutable signs signifying various social or political allegories.

Certainly, revisionist interpretations of 'race' and 'history' undermined the desire for a heroic interpretation of the process of nation-building, and highlighted the Western's role in perpetuating a myth that had sustained America's long-held belief in the virtue of its westward expansion. The advent of the so-called 'pro-Indian' Western resulted in numerous cycles of films that sought to 'update' the genre's ideological functioning for a more liberal 
agenda. Whilst these films offered a degree of what we might call 'mythic redress,' they remained white centric: made by majority white production teams and aimed at mainstream Hollywood audiences. A major characteristic was a re-engagement with the 'good Indian' and 'bad Indian' myth-archetypes. Put simply, the 'good Indian' is positive insofar as he is willing to offer his support for, or at the very least, concede power to, the usurping settlercolonialist social order - to become 'civilized.' The 'bad Indian' is negative because he remains 'savage,' refusing to change with the march of 'progress,' his ideological function serving to justify his own annihilation. Thus the 'pro-Indian' Western was ideologically disingenuous, working to displace rather than deconstruct the genre's structural racism against Native Americans.

A clear example of this is Kevin Costner's Dances with Wolves (1990). Although obstinately taking a significantly more positive approach to Native American culture than most previous Westerns, it maintains a white perspective throughout in the person of its protagonist, a psychologically scarred US Cavalry officer. Furthermore, it dichotomizes the Native American by deliberately offsetting the noble Sioux with the brutish Pawnee. It ends up positing that Native Americans need protecting by the very colonists that decimated their population, only to ultimately suffer a noble but unavoidable defeat at the hands of the technologically superior white man. An example of liberal revisionism in the service of a guilt-ridden culture, it is a Western as white apologetica: ideologically confused on its coloniality and remaining committed to white savior paternalism.

Scott Cooper's Hostiles (2017) falls foul on similar terms. Centered on yet another psychologically scarred US Cavalry officer, its pretensions to reconciling erstwhile warring whites and Indians is undermined by the presence of familiar racial stereotypes and the 'logic' of savage war. As John White assesses the film: “although there are 'good' Native Americans $[\ldots]$ who may once have been enemies but with whom we can now work, there are 
also 'bad' Native Americans who remain our implacable foes and who need to be hunted down and killed before they hunt you down and kill you" (White 2019, 174). Continues White: "Behind black warpaint that erases any sense of common humanity these 'baddies,' these 'outsiders', these cultural 'Other' descend on an idyllic little house on the prairie in the opening scene, destroying it utterly and mercilessly" (White 2019, 174).

When it comes to Native American representation, therefore, the Western appears unable, or, unwilling to escape what Pye describes as the genre's "informing White supremacist terms" (Pye 1996, 229). Despite frequent, even earnest revisionist efforts, "the racism that is inherent in the traditions of the genre makes almost any attempt to produce an anti-racist Western a paradoxical, even contradictory, enterprise" (Pye 1996, 229). With the presence of barely contained racial stereotypes persisting underneath a liberal-revisionist ideological gloss, the traditional narrative confines of the Western demonstrates a limited capacity to 'image the Indian.' By this logic, the Native American could only ever be a sign: a stand-in for a contemporary Other who, for whatever reasons, cannot be addressed directly, and/or, part of a myth-historical imaginary that appeals (however subconsciously) to a colonial era wherein the hegemonic patriarchal white settler social order was, if not unchallenged, certainly unrivalled.

\section{The Western and the Horror in Post-9/11 America}

Such appeal to hegemony was in evidence in America post-9/11. In the days, months, and years following this grievous event, the imagined historical memory of the frontier myth was continuously evoked as a rhetorical strategy at the highest levels of political discourse (and echoed by a largely subservient media) as a way of comprehending the attacks and of justifying America's increasingly violent response. In popular culture, as White observes, films reflected "fears and uncertainties brought about for the United States by the events of 
9/11," with the Western "employed as a space for re-establishing/bolstering a confident, assertive Americanism" (White 2019, 4, 174). The reasons relate directly to the sociopolitical context: "Trauma impacts. A beleaguered culture (naturally) renegotiates its hegemony, restates its values, and attempts to energize its population to resist outside forces that wish to destroy that culture" (White 2019, 175). Thus "the genre par excellence for the expression (and exploration) of the binary opposition of good and evil, civilisation and barbarism" did what it has always done and "responded to the political climate" (White 2019, 175).

Kevin J. Wetmore outlines similar terms for the post-9/11 Horror film, which also sought "to understand, contain and explicate the experience" (Wetmore 2012, 14). Its monsters are readily analogous "to terrorists, [serving] as a synecdoche for that which frightens us. The villains in horror cinema are 'primitive' and evil, especially if human, suggesting the cave-dwelling Taliban that oversaw the planning of the $9 / 11$ attacks" (Wetmore 2012, 44). As such, "primitive human monsters expropriate the horror of 9/11 for the purposes of patriotism, advancing a national narrative that keeps us as 'the good guys' and allows for extreme violence in response to those who would hurt us" (Wetmore 2012, 46). In essence, "Horror justifies fear," and though Horror films post-9/11 often limit "catharsis" in ways that their Western counterparts do not, they likewise "offer us an opportunity to understand the world and to contain and overcome the horror of terror" (Wetmore 2012, 190, 203).

\section{Bone Tomahawk: a Dominant Ideological Reading}

Several aspects of Bone Tomahawk suggest a similar alignment of its dominant ideology to the post-9/11 context. As a Western, it stimulates long-standing cultural fears tied to a mythic version of history that positions white settlers as brave pioneers against a savage threat 
requiring elimination. Using the conventions of Horror, it amplifies these fears to construct its indigenous antagonists as an allegory appropriate to an age of global terrorism. White lists a number of broadly conceived semantic narrative units as to what so-called "War on Terror" Westerns are about. These include "the violent, uncivilised brutality of the enemy with which you are faced," and "the fear of surprise attack, whether in hostile territory, or at home" (White 2019, 175). Accordingly, when the troglodytes attack Bright Hope, it catches the town unawares and unprepared, a symbolic strike at the heart of 'civilization,' a 'hit and run' action alike the 9/11 terrorist attacks upon a complacent America. When they engage the posse, they inject themselves from the periphery of our heroes' field of vision, leaping from behind rocks or descending from low-hanging cliffs. They emerge suddenly, without warning, as if from the very landscape itself. Hunt even describes their desert domain as "hostile territory," thereby making them and the geography they inhabit a suitable metaphor for the Taliban/al-Qaeda and their cave-complex hideouts.

It is in both behavior and appearance that the troglodytes' 'absolute' Otherness is established. Prodigiously tall and caked in white mud, these phantomesque warriors variously adorn themselves with pelts and skulls, attach bones to their bodies, and pierce horns through their faces in grotesque displays of body-modification. Beyond even these terrifyingly macabre accoutrements, the troglodytes all sew a piece of hollowed-out bone into their throats, enabling them to exert a terrifying bestial roar. This last 'customization' compounds their dehumanization at the most fundamental level, rendering them unable to speak and therefore, alike the dominant discourse surrounding terrorists, impossible to reason or negotiate with.

This hard fact is established in a notorious scene from the film in which the troglodytes scalp Nick, upend him, bisect him, and then eat him. There is no hesitation from them, and no chance of a reprieve for the doomed prisoner. This image of abject barbarity 
amplifies the implied "horror" of the Indian in the Western and aligns the troglodytes with monsters from a Horror film. It also links an ideological reading of both genres that is essentially xenophobic, wherein the troglodytes/monsters constitute a deadly external force from somewhere 'out there.' If the Western's 'bad Indian' is the long-demonized savage racial Other to its civilized white settler-colonialist, then the troglodytes are an altogether different breed. They are the Other beyond the Other, diabolical 'prairie demons' that assume a psychological, even metaphysical status, conflating colonialists' worst nightmares of Indian atrocity with contemporary Americans' fears of terrorism. Thus it is no conceptual leap to conflate the troglodytes with the Taliban (or other terrorist groups) who are similarly construed in terms of an outdated metaphysic: 'evil-doers,' cave-dwellers, savages who behead the white enemy invading their territory, who abduct and torture, who cut out and eat the hearts of their victims; an ideologically primitive enemy, an existential threat to America and its 'way of life.'

The connotations of their 'bloodthirsty propensity' thus established, Bone Tomahawk presents the troglodytes as an 'absolute evil.' Drawing its cultural intelligibility from the most ideologically regressive aspects of America's national origin myth, it then amplifies these through Horror imagery to align itself allegorically to a post-9/11 America. Thus we are left with little doubt about the values at stake in the film's core ideological message and of what 'must be done' in the name of their defence. Consequently, Hunt's initial insistence that the posse is here "for a rescue mission, not a massacre," is completely reversed following what happens to Nick. Now Hunt rages that "all of these savages are gonna be massacred!" From savage war to the War on Terror, the ideological message is clear: "the only American response to evil in that sense is to kill it outright" (Wetmore 2013, 199).

Accordingly, Bone Tomahawk concludes with the elimination of the troglodytes. Before this happens, however, and as if we needed further justification for an annihilatory 
'response,' the film invokes the psychosexual fear that inheres in the captivity narrative. When asked by Hunt how many troglodytes there are, Samantha begins to cry. As a look of realization falls across his face, she replies: "Twelve males. Maybe more. Two pregnant females, who are blind cripples." In terms of the myth, it is an ideologically-evocative statement, one indicative of already-occurred rapes, of 'a fate worse than death' had the rescue mission failed and were she forced to 'live' among the troglodytes. The film's penultimate scene emphasizes this by revealing the pregnant females: blinded, their limbs amputated, reduced to breeding machines. It is by far the film's most chilling image and contributes to our current demonizing of Islam: suggestive of paranoiac fears surrounding an understanding of Islamic women as metaphorically blinded and crippled by religious fundamentalism and the burqa; silenced and treated like animals. Within the bounds of its established verisimilitude, Bone Tomahawk comes as close to literalizing a 'figurative descent into Hell' as is possible.

The troglodytes are not the only means by which the sign 'Indian' makes its absent presence felt. Countering their savagery is the dignified figure of the Professor, the aforementioned 'expert' who instructs Hunt on their sinister genealogy. Anton Bitel describes this "dapper Native American" as "as a fount of local knowledge in a desert of colonial ignorance," arguing his presence ensures that the "savage Other" becomes "a mythic monster that can be safely demonised by the filmmakers without fear of offending any real tribe's sensibilities" (Bitel 2016, n.pag.). Bitel likely offers a 'preferred reading,' but in making a "mythic monster" out of the troglodytes, Zahler is merely reengaging with a well-worn stereotype. More than three decades ago, John Tuska forcefully exposed the racism lingering in its premise: "killing 'mythical' Indians is only so much 'newspeak' for enjoying genocide" (Tuska 1985, 260). Chuck Bowen likely comes much closer to the film's real meaning, observing the self-consciousness of a film "skittish about its racism," with the Professor 
"meant to give us permission to root for the killing of 'savages' again, as we might while watching a 1940s-era western produced in less overtly race-conscious times" (Bowen 2015, n.pag.). In its attempt to circumvent charges of racism by having a 'good Indian' be the one to assure us that the troglodytes are not 'Indians,' not even 'bad Indians,' but 'something else entirely,' the film demonstrates its liberal-revisionist conceit: the Professor is a sign of assimilation, a displacement strategy employed in order to permit of a new, unassimilable Other that we can justifiably demonize and kill.

In splitting the sign 'Indian' thus Bone Tomahawk demonstrates a rather blunt ideological contradiction. On the one hand, the film posits a dangerous world of imminent threat, in which liberal values cannot protect civilization (only determined, active masculinity can do that); on the other, it engages the mythological liberal trope of an inclusive and tolerant America. This was the narrative constructed by the White House as a defence of the War on Terror and repeated ad nausea since 9/11: "this great nation of many religions understands, our war is not against Islam, or against faith practiced by the Muslim people. Our war is a war against evil. This is clearly a case of good versus evil, and make no mistake about it - good will prevail" ("Backgrounder"). Not only does this ask us to accept the metaphysical nature of good and evil, its pretentions to liberal tolerance fly in the face of sociopolitical reality. The inclusive and tolerant America is a mystification, wherein the Other can find a place only on the condition that he does not question its inculcated assumptions of white privilege and dominance. It is worth noting here that this reading of the Professor also applies to the film's tokenistic black characters - the doomed Buford, and Gizzard (Maestro Harrell) - both of whom occupy subservient positions within Bright Hope's racial hierarchy.

Frequently forced to distinguish himself from the troglodytes to a suspicious white citizenry, who evidently see 'Indians' as one of a 'kind,' the Professor even has to endure 
Brooder's "ugly boast" about how he has "killed more Indians than any man here." Thus continuously reminded of his difference, the Professor is not the venerable figure the film seems to want him to be. The conditional sympathy afforded him ensures his status is always relative and wholly dependent on the benevolence of the colonist. Underneath it all, the Professor and his 'kind' will never truly 'belong' in the white settler-colonial social order. They will always be reminded of their Otherness, eyed with suspicion; much like Muslim Americans who, despite the sanctimonious liberalist narrative emanating from Washington, continue to be eyed with suspicion: defined through their 'difference,' misrepresented and mistreated, homogenously coded as potentially violent and anti-American: an 'enemy within.'

\section{Reading Bone Tomahawk'Against the Ideological Grain'}

Perhaps because he exemplifies white racism most directly, Brooder is an important character through which to consider the film's inherent ideological contradictions. Visually coded as a gentleman, his actions belie this image, for he is a man defiantly proud of how many Indians he has killed - even women and children. He is this way because his mother and sister were murdered by Indians when he was young, developing in him an unyielding hatred. His generalized notion of revenge aligns him with the "Indian-hater" archetype, a man whose suffering at "savage hands" has made him "an avenger determined at all costs to "exterminate the brutes"” (Slotkin 1992, 16). Here we can see how Zahler's film forges a link to John Ford's The Searchers (1956). Aside from the theme of Indian captivity, "the Indian-hating bigotry of John Wayne's Ethan Edwards is preserved in the character of the trigger-happy Brooder" (Bitel 2016, n.pag.). Also like Edwards, Brooder is a figure onto whom the settler community displaces its own prejudices. Accordingly, other characters are at pains to distance themselves from his overt demonstrations of racism. However, it remains the case 
that 'civilized towns,' as Hunt proudly describes his beloved Bright Hope, relied for their very existence in the first place on the 'savage propensity' of racists like Brooder. It is important to note here that the film effectively acknowledges this in an early scene. Mopping the floor of The Learned Goat, Gizzard asks the owner, Clarence (Fred Melamed), why things are so quiet around town. Clarence replies that the men are off driving "beeves," so “it's just wives, kids, and dead Injuns." Here, Bone Tomahawk effectively acknowledges the 'original crime': Bright Hope, the white settler-colonial social order, and by extension, America itself, was literally built on Native American graves.

Overall, Brooder symbolizes the unpalatable truth that exposes the myth of brave pioneers who 'tamed a continent.' Like Edwards, he could even be read as an unintentional mythoclast, a constant reminder of a disavowed history, of a settler-colonial 'civilization' created by imperialist expansion and genocidal violence. This point is forced home when Brooder guns down two unarmed Mexicans approaching the posse's camp. These actions might be explainable in the narrative context of being in 'hostile territory,' where every stranger is a potential threat; as well, in ideological terms of an allegorical subtext of the War on Terror, in the name of which pre-emptive violence is frequently asserted as a necessity, regardless of 'collateral damage.' Against Hunt's protestations, Brooder insists the men were scouts for a raiding party, stating that if the Sheriff wants to question his morals, he should "do it later." Hunt retorts that "there aren't any to question." Chicory then declares that "Mr. Brooder just educated two Mexicans on the meaning of Manifest Destiny." By clearly and consciously framing Brooder's individual actions within the broader terms of nineteenthcentury America's expansionist policies (which, in addition to forging an empire 'west of the Mississippi' at the expense of the Native Americans, also saw it gain vast tracts of territory from Mexico by means of war), the film is here essentially acknowledging the role played by sheer racialized violence in the founding of the nation. 
However, Bone Tomahawk appears somewhat conflicted, if only tangentially so, on the subject of Brooder's frontier lawlessness. On the one hand, it indicates that he was likely correct in his actions, since the camp is subsequently infiltrated by raiders who steal the posse's horses. On the other, it implies that his actions prompted the raiders to attack in the first place. Ultimately, and whether intentionally or not, Bone Tomahawk passes judgement on its 'outrider' of Manifest Destiny. Having built himself up through braggadocio as an 'Indian killer' and as 'the smartest man' among his peers, Brooder is the first among them to be killed by the troglodytes. Compounding this undermining is the irony that the 'Indian killer' fails to kill any of the 'race enemy' he hates so much.

Drawing away from issues of race for a moment, the representation of women and female agency in the film suggests a different kind of ideological ambiguity. As a Western, Bone Tomahawk remains typical for a genre that stresses traditional forms of masculinity whilst relegating women to the margins, with the recrudescence of "passive femininity" particularly noticeable in popular culture following 9/11 (Wetmore 2012, 14-16). However, though the film's female roles are, indeed, marginal, they are hardly passive. First, there is Mrs. Porter (Sean Young), wife of the Mayor (Jamie Newlander). Standing over him both literally and figuratively, it is she the narrative suggests who represents the true authority in Bright Hope. It is to Mrs. Porter that Hunt addresses the important matter of the kidnapping, despite her remonstration that he should "address the Mayor directly." Humorously, it is noticeable that Mrs. Porter ignores her husband as much as Hunt does. Then there is Samantha who, although playing a traditional role as the object of rescue, displays something of the qualities of the 'Hawksian' woman: independence, courage, dependability, and strong mindedness. She also delivers a pointed counter to the film's masculinist ideology when she excoriates Hunt and Chicory: "This is why frontier life is so difficult. Not because of the Indians, or the elements, but because of the idiots. You're idiots!" Whilst this limited use of 
female agency does not significantly affect the film's ideological dynamic, both Mrs. Porter and Samantha can be said to offer marginal opposition to its enactment of traditionally delineated social roles predicated on patriarchal dominance and an otherwise unabashed endorsement of male heroism.

It could be argued that Bone Tomahawk actually undermines its own ideological coherence from the outset. The opening shot shows a man's throat being slit before moving to a wide shot revealing the bodies of three white men who Buddy and Purvis have just murdered for whatever they can steal. It is shortly after that they stumble on the troglodyte's territory. Against Purvis's caution that they should not walk "through a place that looks like a burial ground," Buddy responds by declaring that what is sacred "to a bunch of goddamned savages ain't no concern of the civilized man!" Brandishing his gun, he follows up with "we got permission!" In response to a strange noise, Buddy says: "We're coming through here, like it or not!" He shoots aimlessly before receiving a troglodyte arrow in the throat and being disembowelled. In a curious way, this opening sequence effectively plays out American expansionism in microcosm. The gun is the 'permission,' the concerns of the 'savage' disregarded, and the irony of the 'savage propensity' of the white man demonstrated. One could make the argument that, as bandits, the pair are outside the ideological confines of 'civilization' and are therefore figurative 'savages' themselves. However, given what we know about the reality of the settler-colonialist project, it is interesting that, in an otherwise reactionary film, the first white men we are introduced to are murderers, thieves, and invaders.

\section{Conclusion}

This article has argued that Bone Tomahawk expresses a dominant ideology linked to a post9/11 America. In many ways reflective of reactionary conservative political and cultural 
attitudes, it reinforces belief in American exceptionalism, expresses a paranoid fear of the Other, and justifies the use of extreme violence as a necessary defence of 'civilization' against an external threat. At the same time, and to a lesser extent, I have suggested that the film also embodies certain uncontained ideological contradictions that, though undeveloped, could be said to contest the coherence of this expression.

In line with the political-ideological tenets of the War on Terror, Bone Tomahawk suggests that 'evil' must be confronted and destroyed. Thus we can read the film as an allegorical representation of a feared contemporary Otherness in a period of heightened sociopolitical anxiety that looks to reduce the complexities of the world to the opposed, mythological forces of 'good' and 'evil.' However, since the very notion of unmotivated evil is an ideological device for pre-empting analysis, we must confront an endemic issue afflicting American culture. There is an inherent dis-ease in the national psyche about its history that results in its continual replaying and reframing it within terms of a debilitating, culturally entrenched mythology. In times of crisis, America habitually reverts to 'Western' rhetoric of Manifest Destiny, Native American 'savagery,' and 'off the reservation' civilizing missions in times of war and external conflict that threaten its sense of righteous superiority. This creates an ideological mirror that America often gazes into to see a distorted, idealized image reflected back. That this image, this mythic version of history is preferred to anything that we might call 'reality,' suggests an ideological consistency between savage war and the War on Terror, between the violent past and the violent present.

Undoubtedly, decades of historical 'revisionism' have served to highlight the role of the Western genre in perpetuating the myth of the 'domestication of the wilderness,' and to remind us of the process whereby this myth was constructed to justify Manifest Destiny. With its deconstruction of myth, revisionism has been, and continues to be, particularly important in making us aware of the way in which myth serves the often unconscious and 
always powerful need for society to justify its own history. That no myth-free culture can exist places on the scholar of texts - significant or otherwise - the duty of scepticism and the need for the awareness to recognize mythic structures when they see them. Although the Western is not the cultural force it once was, a film like Bone Tomahawk, as insignificant in and of itself as it is, exists as a product of a society still demonstrably seduced by its settlercolonialist mythology. It is both an instance and reflection of how America continues to appropriate the mythic past to define and address the crises of the present.

\section{Works Cited}

"Backgrounder: The President's Quotes on Islam." The White House: President George W. Bush. $\quad<$ https://georgewbush-whitehouse.archives.gov/infocus/ramadan/islam.html > (May 20, 2019).

Bitel, Anton (2016). "Film of the Week: Bone Tomahawk." Sight \& Sound. $<$ https://www.bfi.org.uk/news-opinion/sight-sound-magazine/reviewsrecommendations/film-week-bone-tomahawk> (June 29, 2019).

Bone Tomahawk (2015). Dir. S. Craig Zahler. Caliber Media Company.

Bowen, Chuck (2015). "Bone Tomahawk Film Review." Slant Magazine. $<$ https://www.slantmagazine.com/film/bone-tomahawk/> (June 29, 2019).

Cawelti, John G. (1999). The Six-Gun Mystique Sequel. Bowling Green, OH: Bowling Green State University Popular Press.

Dances with Wolves (1990). Dir. Kevin Costner. Orion Pictures.

Hamilton, Emma and Alistair Rolls (2018). "Introduction. Editors on Auteurs: Thoughts on Auteurism from the Frontier." Emma Hamilton and Alistair Rolls, eds. Unbridling the 
Western Film Auteur: Contemporary, Transnational and Intertextual Explorations. Oxford. Peter Lang, 1-25.

Hostiles. (2017). Dir. Scott Cooper. Entertainment Studios.

Kollin, Susan (2001). "Genre and the Geographies of Violence: Cormac McCarthy and the Contemporary Western." Contemporary Literature 42.3, 557-588.

Maltby, Richard (1996). "A Better Sense of History: John Ford and the Indians." Ian Cameron and Douglas Pye, eds. The Movie Book of the Western. London: Studio Vista, 34-49.

Nelson, Andrew Patrick (2013). “Introduction: The American Western, 1990-2010.” Andrew Patrick Nelson, ed. Contemporary Westerns: Film and Television since 1990.

Lanham, MD: The Scarecrow Press, xiii-xxi.

Pye, Douglas (1996). "Double Vision: Miscegenation and Point of View in The Searchers." Ian Cameron and Douglas Pye, eds. The Movie Book of the Western. London: Studio Vista, 229-235.

The Searchers (1956). Dir. John Ford. Warner Bros.

Slotkin, Richard (1992). Gunfighter Nation: The Myth of the Frontier in Twentieth-Century America. Norman, OK: University of Oklahoma Press.

Wetmore, Kevin J (2012). Post-9/11 Horror in American Cinema. New York, NY: Continuum.

White, John (2019). The Contemporary Western: An American Genre Post-9/11. Edinburgh: Edinburgh University Press. 